\title{
RESTRICCIONES A LA LIBERTAD DE EMPRESA Y EL MERCADO EN LA NORMATIVA URBANÍSTICA APLICABLE A LAS VIVIENDAS VACACIONALES
}

\author{
Restrictions on the freedom of business and the market \\ in the urban regulations applicable to vacation housing
}

\author{
Juan Franch Fluxà \\ Profesor contratado doctor de Derecho Mercantil \\ Universitat de les Illes Balears
}

http://dx.doi.org/10.18543/ed-69(2)-2021pp43-76

Recibido: 8.12.2021

Aceptado: 13.12 .2021

\section{Resumen}

Este trabajo analiza los problemas derivados de las legislaciones autonómicas y locales en el sector turístico cuando las viviendas vacacionales se someten a restricciones que podrían ser contrarias a la regulación eficiente. Los tribunales han analizado las medidas urbanísticas a las viviendas que se comercializan turísticamente atendiendo a la Directiva de Servicios y otros principios y normas tanto europeos como nacionales.

\section{Palabras clave}

Derechos y libertades fundamentales, eficiencia del mercado, derecho de la competencia, razones imperiosas de interés general, alquiler vacacional, zonificación, medidas administrativas.

\section{Abstract}

This paper analyzes the problems arising from regional and local regulations affecting the tourism sector when holiday homes are subjected to restrictions that could be contrary to efficient regulation. The courts have analyzed the urban planning 
measures for the commercialization of short term accomodations in holiday homes, in accordance with the Services Directive and other european and national principles and legislation.

\section{Keywords}

Fundamental rights and freedoms, market efficiency, competition law, overriding reasons of general interest, holiday rentals, zoning, administrative measures. 
SUMARIO: I. INTRODUCCIÓN. II. LA CONFRONTACIÓN DE INTERESES GENERALES Y DERECHOS EN CONFLICTO. III. LA EXIGENCIA PRINCIPIO DE BUENA REGULACIÓN. IV. LA NORMATIVA DE VUT COMO EJEMPLO DE LIMITACIÓN DE LA COMPETENCIA EN EL ÁMBITO TURÍSTICO. V. LA ZONIFICACIÓN TURÍSTICA COMO TÉCNICA RESTRICTIVA. VI. CONCLUSIONES. VII. BIBLIOGRAFÍA.

\section{INTRODUCCIÓN}

Las normativas autonómicas y locales que regulan y afectan a la oferta turística en viviendas han generado diversos debates de profundo calado que, para este texto, vamos a circunscribir a la confrontación de intereses y derechos propiciada por determinadas medidas de naturaleza urbanística cuya técnica legislativa puede ser cuestionable.

Una de las principales dudas que suscita la tendencia actual de ordenación del turismo (orientada más a su prohibición que a una correcta racionalización u ordenación de las ciudades y las infraestructuras o recursos) pasa por resolver si las zonificaciones que están aprobando los distintos municipios son un obstáculo a la competencia efectiva en el mercado que propugna el artículo 38 de la Constitución. Restricciones o prohibiciones administrativas que privan a los gestores y propietarios (con independencia del carácter o no de grandes tenedores) de las facultades previstas en el artículo 33 de nuestra Carta Magna ${ }^{1}$. Medidas que, además, pueden generar notorias diferencias que podrían cuestionar otro de los postulados constitucionales que sustentan nuestro ordenamiento jurídico como es el de igualdad ante la ley y no discriminación (artículo $14 \mathrm{CE}$ ). Como apuntaremos, la clave para la comprensión de un debate que ya se ha judicializado en diversas ocasiones se sustenta en el análisis de dichas restricciones y su justificación desde el punto de su necesidad y proporcionalidad que han sido debida y extensamente interpretadas.

Resulta paradójico que estas barreras de entrada — de distinta índole que se están generalizando en las distintas normativas locales, regionales o autonómicas - afecten al sector económico principal de nuestro país y, por lo tanto, resulta más complejo entender que pueda existir un interés general superior que prime dentro de las razones imperiosas de interés general, concepto que debe interpretarse a partir de la categorización realizada por el ordenamiento europeo y diversos pronunciamientos del propio TJUE que se citarán a lo largo de este trabajo.

${ }^{1}$ Con carácter monográfico y extensamente desarrollado, Rey Martínez, F. La propiedad privada en la Constitución española, Colección Estudios Constitucionales, Centro de Estudios Políticos y Constitucionales, Madrid, 1994. 
Estamos ante un nuevo dilema normativo, si bien conviene recordar que no estamos ante un fenómeno nuevo para el legislador puesto que la novedad exclusivamente reside en la popular y exitosa forma de comercialización online que afecta a la oferta turística y también a muchos otros mercados ${ }^{2}$. Es indudable que las viviendas de uso turístico están ampliamente consolidadas en nuestro país y buena prueba de ello es su regulación por medio de la Orden de 17 de enero de 1967 por la que se aprueba la ordenación de los apartamentos, bungalows y otros alojamientos similares de carácter turístico y especialmente por el artículo 17 del Decreto 2877/1982 que establece una definición de este tipo de alojamientos turísticos donde se incluyen las viviendas vacacionales $^{3}$. Cabe apuntar que sobre estas definiciones y categorías no ha habido grandes cambios, pero sí que las normas actuales han precisado este marco fijando nuevos requisitos que son de obligado cumplimiento ${ }^{4}$.

Finalmente queremos apuntar una visión que no compartimos donde la vivienda turística se presenta como una manifestación de un uso abusivo o inadecuado de la propiedad y que sería sancionable conforme a lo previsto en el artículo 7.2 del Código Civil que prescribe el abuso de derecho y con ello el ejercicio antisocial del mismo ${ }^{5}$. Ello plantea que se puedan sobrepasar los límites normales del ejercicio de un derecho de lo que debe derivar, además, un daño para tercero. El excesivo intervencionismo que caracteriza a los actuales poderes públicos nos lleva a recordar que ante ello es muy probable que ya existiesen decisiones judiciales y otras medidas administrativas que impedirían dichos abusos ${ }^{6}$.

${ }^{2}$ Sobre los retos legales que generan las plataformas, AA.VV. (Directores Muñoz, A./Rodríguez, S.), Aspectos legales de la economía colaborativa y bajo demanda en plataformas digitales, Bosch, Madrid 2018.

${ }^{3}$ Se fija una clara definición entre apartamentos y viviendas turísticas dependiendo entre otros motivos del uso terciario o no del suelo donde radican. Determina en su artículo 17: No tendrán la consideración legal de apartamentos turísticos, sino de viviendas turísticas vacacionales las unidades aisladas de apartamentos, bungalows, villas y chalés y similares $y$, en general cualquier vivienda que, con independencia, de sus condiciones de mobiliario, equipo, instalaciones y servicios, se ofrezcan en régimen de alquiler por motivos vacacionales o turísticos.

${ }^{4}$ A modo de ejemplo del listado de requisitos puede consultarse el Decreto catalán 159/2012, de 20 de noviembre, de establecimientos de alojamiento turístico y de viviendas de uso turístico en su artículo 67 o la Ley 8/2012, de 19 de julio del turismo de las Illes Balears, en su artículo 50.

5 Abogando por una normalización de la actividad al amparo de una adecuada normativa turística. Franch Fluxà, J. «La regulación de la vivienda de uso turístico en Baleares tras las últimas reformas legislativas» en AA.VV. (Directoras González Cabrera, I./Rodríguez, M.P.) Las viviendas vacacionales: entre la economía colaborativa y la actividad mercantil, Dykinson, Madrid, 2019, págs.145-168.

${ }^{6}$ Indica Fernández Torres que a la hora de regular las viviendas vacacionales el estado, las CCAA y las corporaciones locales «introducen distintos mecanismos de interven- 


\section{LA CONFRONTACIÓN DE INTERESES GENERALES Y DERECHOS EN CONFLICTO}

La regulación de esta actividad económica pone de relieve la necesidad de entender la ponderación de derechos constitucionales y la trascendencia de la constitución económica ${ }^{7}$. Conforme al artículo 38 de la Constitución es una obligación de todos los poderes públicos garantizar el ejercicio de la libertad de empresa, por lo tanto, la actuación administrativa debe procurar o defender el funcionamiento eficaz y competitivo de los mercados y, para ello, deberá evitarse cualquier acto o disposición que pueda suponer una limitación o restricción a este fin. Obviamente, en el caso de que dichas medidas fuesen necesarias deberán ponderarse los intereses que se persiguen con aquellos que se viesen afectados relativos al buen funcionamiento del mercado.

Las pautas de acceso al mercado están claramente definidas en la Directiva 2006/123/CE del Parlamento Europeo y del Consejo, de 12 de diciembre de 2006, relativa a los servicios en el mercado interior (en adelante Directiva de servicios) que impone que solo pueden someterse a los prestadores de servicios a requisitos de acceso al mercado u otro tipo autorizaciones o concesión de licencias en la medida en que no sean discriminatorias, que sean necesarias para alcanzar un objetivo de interés público claramente identificado (artículo 4.8) y que sean proporcionados a dicho objetivo del mismo (artículo 4.6 y Considerando 39). Todo ello se impone también con respecto a los servicios profesionales por la Directiva 2005/36/CE del Parlamento Europeo y del Consejo, de 7 de septiembre de 2005, relativa al reconocimiento de cualificaciones profesionales ${ }^{9}$.

Existe en la actividad objeto de este análisis un ecosistema de intereses en juego que ha generado que uno de los destacados debates relacionados con la normativa de las VUT sea determinar si la técnica del planeamiento

ción administrativa con escaso rigor, deficiente técnica normativa y, lo que es aún peor, poca o nula preocupación por la observancia de límites infranqueables que el Derecho Administrativo impone con el respaldo indispensable de la Constitución Española de 1978». Fernández Torres, J.R. «No todo vale a la hora de controlar las viviendas vacacionales», Revista Aranzadi de Urbanismo y Edificación n. ${ }^{\circ}$ 42/2018, Tribuna, pág. 13.

7 Vid. Gordillo Pérez, L. I./Rodríguez Ortiz, F. Constitución económica y gobernanza económica de la UE, Thomson-Aranzadi, Madrid, 2019.

${ }^{8}$ Con mayor extensión en Jiménez Soto I. «Ordenación de los servicios turísticos: competencias administrativas y unidad de mercado» en AA.VV. Vandelli, L./Font i Llovet T.) Ordenación jurídico-administrativa del Turismo, Atelier, Barcelona, 2018 págs. 21-78.

${ }^{9}$ Modificada por la Directiva 2013/55/UE del Parlamento Europeo y del Consejo, de 20 de noviembre de 2013, que ha sido incorporada a nuestro ordenamiento jurídico por el Real Decreto 581/2017, de 9 de junio, regula el procedimiento de reconocimiento de títulos obtenidos en la Unión Europea para el ejercicio de profesiones reguladas en España. 
que persigue configurar un determinado modelo de ciudad encaja dentro de las «razones imperiosas de interés general» tal como éstas han sido debidamente interpretadas y definidas por el Tribunal de Justicia de la Unión Europea.

Como es sabido, no cabe una interpretación abstracta de «Razón imperiosa de interés general» que se circunscribe a las siguientes materias: el orden público, la seguridad pública, la protección civil, la salud pública, la preservación del equilibrio financiero del régimen de seguridad social, la protección de los derechos, la seguridad y la salud de los consumidores, de los destinatarios de servicios y de los trabajadores, las exigencias de la buena fe en las transacciones comerciales, la lucha contra el fraude, la protección del medio ambiente y del medio o entorno urbano ${ }^{10}$, la sanidad animal, la propiedad intelectual e industrial, la conservación del patrimonio histórico y artístico nacional y los objetivos de la política social y cultural.

El imperio de la libertad de empresa y el desarrollo de cualquier actividad económica exclusivamente queda condicionado por la concurrencia de alguno de los motivos señalados y que son expresamente tasados. Dicho esto, la libertad de establecimiento de los prestadores de servicios y el ejercicio de la libre prestación de servicios son dos derechos que se encuentran protegidos por la Directiva de servicios y las leyes de transposición en España. La Directiva y la normativa nacional afectan a cualquier acto o disposición de las administraciones públicas que contenga requisitos que regulen de manera específica actividades de servicios ${ }^{11}$.

Por lo tanto, el ejercicio de la actividad turística es libre y a lo sumo solo puede condicionarse por las limitaciones que pudiera imponer la legislación vigente como, por ejemplo, advierte el artículo 21 de la Ley de turismo de Balears ${ }^{12}$. Por tanto y atendiendo también a criterios que sustentan la Ley 20/2013, de 9 de diciembre, de garantía de la unidad de mercado, en adelante LGUM, cualquier operador puede establecerse en cualquier región de nuestro país y para ello es suficiente hacerlo a través de una declaración responsable o comunicación conforme se determine en las leyes o decretos turísticos de cada comunidad autónoma.

${ }^{10}$ En la STSJ País Vasco de 11 de junio de 2019 se legitiman las restricciones para conciliar la satisfacción del derecho a la vivienda con el destino de determinadas viviendas al alojamiento turístico y para la protección del medio urbano.

11 Véase el artículo 4 relativo a definiciones. En nuestra legislación art. 3 (definiciones) de la Ley 17/2009, de 23 de noviembre, sobre el libre acceso a las actividades de servicios y su ejercicio.

${ }_{12}$ Cualquier persona interesada en la prestación de servicios relacionados con la actividad turística puede establecerse en las Illes Balears, previa presentación de la declaración responsable o de la comunicación y la obtención de la habilitación oportuna, en su caso, en los términos legalmente o reglamentariamente establecidos. 
Partimos de la base que un catálogo de medidas que afecte particularmente a las empresas turísticas de comercialización de estancias turísticas en viviendas probablemente colisione potencialmente con el derecho de libertad de empresa; si bien resulta complejo solucionar esa fricción entre el urbanismo y la libertad de empresa puesto que si con carácter apriorístico primara esta última también podrían quedar desvirtuadas las competencias urbanísticas de las corporaciones locales ${ }^{13}$. Entendemos que llegados a esta disyuntiva solo puede resolverse dicha colisión conforme a la aplicación y comprensión de la existencia de una razón imperiosa de interés general.

Curiosamente es en las comunidades autónomas que sustentan su economía principal y únicamente sobre la industria turística donde se ha regulado considerando el turista o turismo como elemento nocivo. Entre los derechos afectados se alega, con un carácter secundario, que actividad turística en determinadas zonas atentaría contra la intimidad personal y familiar contenida en el artículo 18 de la Constitución, la protección social y jurídica de la familia y la salud de las personas que son exigencias que los artículos 39 y 43 de la Constitución imponen a los poderes públicos. Más peso y trascendencia se ha dado al artículo 47 Constitución, extremadamente controvertido y frecuentemente alegado, que contiene el derecho a disfrutar de una vivienda digna y adecuada que se traduce en el mandato a los poderes públicos para promover las condiciones necesarias y establecer las normas pertinentes para hacer efectivo este derecho, básicamente mediante la utilización del suelo conforme al interés general ${ }^{14}$.

La contraposición de intereses y la preservación de derechos constitucionales ha sido el telón de fondo del debate sobre la regulación de la actividad turística en viviendas que sirve de marco para nuestras reflexiones. Por ejemplo, las administraciones han esgrimido la vertiente social del derecho de la propiedad privada reconocido en el artículo 33.1 de la Constitución ${ }^{15}$, entendiendo que no admite injerencias en clave de relaciones de vecindad como limitación del derecho de dominio que impidan el normal uso de las faculta-

13 Vid. Doménech Pascual, G. «La regulación autonómica y local de las viviendas de uso turístico», en Anuario de Derecho Municipal 2017, n. ${ }^{\circ}$ 11, págs. 43-73.

${ }^{14}$ Así en la Sentencia del TJUE (Sala Primera) de 8 de mayo de 2013 (C-197/11 y C-203/11) se indica que las exigencias «relativas a la política de vivienda social de un Estado miembro pueden ser razones de interés general y, por tanto, justificar restricciones» (apartado 52).

15 Algunos de los asuntos enjuiciados por el Tribunal Europeo de Derechos Humanos (TEDH) analizan la revocación y cambios de licencia o el control de rentas. Vid. Págs. 23-24 (especialmente punto 101 y 103) European Court of Human Rights, Guide on Article 1 of Protocol No. 1 to the European Convention on Human Rights-Protection of property (actualizado a 31 de agosto de 2021) < https://www.echr.coe.int/Documents/Guide_Art_1_Protocol_1_ENG.pdf> 
des que integran su contenido. Un claro ejemplo de la repercusión directa de la utilización de las viviendas de uso turístico sobre la convivencia vecinal ${ }^{16}$ es la normativa de Barcelona.

El hecho de encontrarnos ante comunidades de propietarios pone claramente de manifiesto el efecto sobre la colectividad que presentarán actos de disposición o uso de las viviendas y que debe valorarse y regularse a partir de las normas internas que fije la propia comunidad. Estos actos son y deben considerarse aceptables siempre que esa influencia no resultara nociva para los demás integrantes de la comunidad. Ello nos lleva al normal uso de la propiedad conforme a las costumbres y las relaciones sociales que hasta el momento no habían entrado a cuestionarse en función del título de cesión de las viviendas a terceros bajo distintas modalidades de arrendamiento reconocidas en la Ley de arrendamientos urbanos, que en 2014 remite el alquiler vacacional a la normativa sectorial autonómica.

Un último derecho objetivo político que afecta a toda la actividad turística es el derecho a disfrutar de un medio ambiente ${ }^{17}$ adecuado para el desarrollo de las personas, así como el deber de conservarlo por este motivo como prescribe el artículo 45 de la Constitución; los poderes públicos tienen la obligación de velar para utilización racional de todos los recursos naturales con el fin de proteger y mejorar la calidad de la vida y defender y restaurar el medio ambiente al amparo de la solidaridad colectiva. El turismo en determinados discursos y actuaciones se entiende como un depredador de recursos.

Para ejemplificar lo anterior podemos citar Andalucía donde como razón de interés general para justificar proceder a la regulación de estas viviendas con fines turísticos se esgrime la protección del medio ambiente y el entorno urbano. Es uno de tantos ordenamientos donde se manifiesta la preocupación por el impacto de la incidencia de esta actividad sobre el territorio ${ }^{18}$.

${ }^{16}$ Expresamente Canarias Aragón y Asturias exigen que se acredite que dicha actividad no se encuentra prohibida por los estatutos de la Comunidad de propietarios. Vid. Goñi Rodríguez de Almeida, M. «El alquiler vacacional como actividad molesta en la comunidad de propietarios», Revista Crítica de Derecho Inmobiliario, n. ${ }^{\circ} 765$, enero, 2018, págs. 496-512. En cuanto a la toma de decisiones y el artículo 17 de la Ley de propiedad horizontal, vid. Fuentes-Lojo Rius, A. «Problemática del propietario múltiple en la adopción de acuerdos comunitarios», Diario La Ley, N. ${ }^{\circ}$ 9539, 18 de diciembre de 2019, Editorial Wolters Kluwer (consulta online)

${ }_{17}$ El medio ambiente primaría sobre el derecho a la propiedad en algunos casos enjuiciados por el TEDH Con especial desarrollo en el punto 130 Guide on Article 1 of Protocol No. 1 ... ob. cit., pág. 28

18 Serrano García, M. «La ordenación legal de los establecimientos de apartamentos turísticos en Andalucía». Revista Internacional de Turismo, Empresa y Territorio, 4 (2), 2020, 212-220. <https://doi.org/10.21071/riturem.v4i1.13118>. 


\section{LA EXIGENCIA PRINCIPIO DE BUENA REGULACIÓN}

Cualquier injerencia en el funcionamiento de los mercados deberá ir precedido de una correspondiente ponderación entre los intereses que persigan esas normas limitativas y los beneficios que tienen el funcionamiento competitivo de los mercados ${ }^{19}$. Como queda expresamente determinado en el artículo 129 Ley 39/2015, de 1 de octubre, del Procedimiento Administrativo Común de las Administraciones Públicas, son aplicables los principios de necesidad, proporcionalidad y no discriminación en la regulación de las actividades económicas ya que son principios previstos tanto en el derecho comunitario como en el propio ordenamiento español. Ese control de la intervención administrativa está claramente reflejado en el artículo 4.1 de la Ley 40/2015, de 1 de octubre, de Régimen Jurídico del Sector Público ${ }^{20}$.

Sí consideramos oportuno reproducir el artículo 5 de la LGUM ya que específicamente aborda los límites al acceso de una actividad económica o su ejercicio:

1. Las autoridades competentes que en el ejercicio de sus respectivas competencias establezcan límites al acceso a una actividad económica o su ejercicio de conformidad con lo previsto en el articulo 17 de esta Leyo exijan el cumplimiento de requisitos para el desarrollo de una actividad, motivarán su necesidad en la salvaguarda de alguna razón imperiosa de interés general de entre las comprendidas en el artículo 3.11 de la Ley 17/2009, de 23 de noviembre, sobre el libre acceso a las actividades de servicios y su ejercicio.

2. Cualquier límite o requisito establecido conforme al apartado anterior, deberá ser proporcionado a la razón imperiosa de interés general invocada, y habrá de ser tal que no exista otro medio menos restrictivo o distorsionador para la actividad económica.

Observamos, pues, que no estamos ante una cuestión sectorial y son diversas las normativas que le impiden a las administraciones públicas imponer

${ }^{19}$ Coincidimos con Fernández Torres que las diversas normativas sobre el alquilar vacacional no sopesan los diversos intereses en juego y que esa voluntad conciliadora se puede y debe exigir a la administración pública como reguladora y arbitro del mercado. Vid. Fernández Torres, J.R. «No todo vale a la hora de...», ob.cit., pág. 15.

${ }^{20}$ Artículo 4 Principios de intervención de las Administraciones Públicas para el desarrollo de una actividad:

1. Las Administraciones Públicas que, en el ejercicio de sus respectivas competencias, establezcan medidas que limiten el ejercicio de derechos individuales o colectivos o exijan el cumplimiento de requisitos para el desarrollo de una actividad, deberán aplicar el principio de proporcionalidad y elegir la medida menos restrictiva, motivar su necesidad para la protección del interés público así como justificar su adecuación para lograr los fines que se persiguen, sin que en ningún caso se produzcan diferencias de trato discriminatorias. Asimismo deberán evaluar periódicamente los efectos y resultados obtenidos. 
medidas limitativas o restrictivas de la competencia amparándolas en criterios económicos ${ }^{21}$. Aunque, como insistiremos, tampoco puede hacerse de manera indirecta invocando razones imperiosas de interés general que en su esencia encubren requisitos u objetivos de planificación económica ${ }^{22} \mathrm{Al}$ respecto ya se han pronunciado en diversas ocasiones el TJUE en Sentencia del Tribunal de Justicia de 4 de junio de 2002, Comisión de las Comunidades Europeas contra República Portuguesa (Asunto C-367/98) o Sentencia del Tribunal de Justicia (Sala Segunda) de 24 de marzo de 2011, Comisión Europea contra Reino de España (asunto C-400/08) 31/16 en el ámbito nacional el Tribunal Supremo en Sentencia, n. ${ }^{\circ}$ 1974/2016, de 21 de junio de $2016^{23}$.

Los principios de buena regulación nos llevan a conectar la necesidad a una razón imperiosa de interés general tasadas en la directiva de servicio y leyes de transposición: la proporcionalidad implica satisfacer un doble requerimiento: la idoneidad de la medida, es decir que sea adecuada al fin que pretende alcanzar y, en segundo lugar, que presente una mínima restricción, que entendemos queda comprometida en aquellos supuestos que establezcan prohibiciones absolutas ${ }^{24}$.

21 Vid. Artículo $18.2 \mathrm{~g}$ LGUM.

${ }^{22}$ En este sentido el art. 10 e Ley 17/2009 impone que en ningún caso se supeditará el acceso a una actividad de servicios en España o su ejercicio al cumplimiento de lo siguiente: (...) e) Requisitos de naturaleza económica que supediten la concesión de la autorización a la prueba de la existencia de una necesidad económica o de una demanda en el mercado, a que se evalúen los efectos económicos, posibles o reales, de la actividad o a que se haga una apreciación de si la actividad se ajusta a los objetivos de programación económica fijados por la autoridad competente o a que se comercialicen productos o servicios de un tipo o procedencia determinada. Las razones imperiosas de interés general que se invoquen no podrán encubrir requisitos de planificación económica.

${ }^{23}$ En su F.J Quinto: «4. En ningún caso, podrán establecerse requisitos de naturaleza económica, entre otros, aquellos que supediten el otorgamiento de la autorización a la prueba de la existencia de una necesidad económica o de una demanda en el mercado o a un exceso de la oferta comercial, a que se evalúen los efectos económicos, posibles o reales, de la actividad o a que se haga una apreciación de si la actividad se ajusta a los objetivos de programación económica establecidos por la autoridad competente, o aquellos que puedan directa o indirectamente ir dirigidos a la defensa de un determinado modelo económico o empresarial dentro del sector. Asimismo se prohíbe la intervención de competidores en los procedimientos de autorización que en su caso se establezcan para la instalación de establecimientos comerciales.»

${ }^{24}$ Como se indica en la Guía sobre el artículo 1 del Convenio Europeo de Derechos Humanos: El propósito de la prueba de proporcionalidad es establecer primero cómo y en qué medida el solicitante fue restringido en el ejercicio del derecho afectado por la intervención o medida denunciada y cuáles fueron las consecuencias adversas de la restricción impuesta al ejercicio de los derechos del solicitante o en su situación. Posteriormente, este impacto se equilibra con la importancia del interés público que motivó la intervención. Así se describe en el punto 145 Guide on Article 1 of Protocol No. 1... ob. cit., pág. 30. 
Todo lo indicado queda perfectamente reflejado en la Sentencia del Tribunal de Justicia (Sala Tercera) de 16 de abril de 2015, Comisión Europea contra República Federal de Alemania (C-591/13): "Conforme a reiterada jurisprudencia, una normativa nacional sólo puede limitar la libertad de establecimiento si la restricción en cuestión está justificada por razones imperiosas de interés general. En tal supuesto es preciso, además, que esa restricción sea adecuada para garantizar la realización del objetivo de que se trate y que no vaya más allá de lo necesario para alcanzarlo (véase la sentencia DI. VI. Finanziaria di Diego della Valle \& C., C-380/11, EU:C:2012:552, apartado 41 y jurisprudencia citada) $\rangle^{25}$.

Ya en la Sentencia del Tribunal de Justicia de 22 de enero de 2002, Canal Satélite Digital SL contra Administración General del Estado, en el que participa Distribuidora de Televisión Digital SA (DTS) (Asunto C-390/99) ya recoge una serie de precedentes judiciales donde se fija esta necesidad: «En consecuencia, la cuestión de si las restricciones mencionadas en el apartado 29 de la presente sentencia están justificadas debe examinarse simultáneamente a la luz de los artículos 30 y 59 del Tratado, con el fin de apreciar si la medida nacional controvertida en el procedimiento principal persigue una finalidad de interés general y respeta el principio de proporcionalidad, es decir, si es adecuada para garantizar la realización del objetivo que pretende lograr y no va más allá de lo necesario para alcanzarlo (véanse, en particular, las sentencias de 25 de julio de 1991, Säger, C-76/90, Rec. p. I-4221, apartado 15; de 23 de noviembre de 1999, Arblade y otros, asuntos acumulados C-369/96 y C-376/96, Rec. p. I-8453, apartado 35, y Corsten, antes citada, apartado 39)..${ }^{26}$

Para la idoneidad y adecuación se reitera que debe conectarse al objetivo de manera congruente y sistemática como bien expresa la Sentencia del Tribunal de Justicia (Sala Primera) de 11 de junio de 2015, Berlington Hungary Tanácsadó és Szolgáltató kft y otros contra Magyar Állam (Asunto C-98/14): «Sin embargo, las restricciones impuestas por los Estados miembros deben cumplir los requisitos de proporcionalidad derivados de la jurisprudencia del Tribunal de Justicia, es decir, que sean adecuadas para garantizar el cumplimiento del objetivo perseguido y que no vayan más allá de lo necesario para alcanzarlo. Además, debe recordarse en este contexto que una normativa nacional sólo es adecuada para garantizar la consecución del objetivo invocado si responde efectivamente al propósito de lograrlo de forma coherente y sistemática (véase la sentencia HIT y HIT LARIX, C-176/11, EU:C:2012:454, apartado 22, y la jurisprudencia citada).. ${ }^{27}$

\footnotetext{
25 Apartado 63.

26 Apartado 33.

27 Apartado 64.
} 
Las restricciones que se puedan imponer por las administraciones nunca pueden ser discriminatorias como queda expresamente manifestado en la Sentencia del Tribunal de Justicia (Sala Cuarta) de 12 de julio de 2012, HIT hoteli, igralnice, turizem dd Nova Gorica e HIT LARIX, prirejanje posebnih iger na srečo in turizem dd contra Bundesminister für Finanzen (Asunto C-176/11): «Sin embargo, las restricciones impuestas por los Estados miembros deben cumplir los requisitos que se derivan de la jurisprudencia del Tribunal de Justicia en lo que respecta a su proporcionalidad, es decir, que sean adecuadas para garantizar el cumplimiento del objetivo perseguido y que no vayan más allá de lo necesario para alcanzarlo. Además, debe recordarse, en este contexto, que una normativa nacional sólo es adecuada para garantizar la consecución del objetivo alegado si responde verdaderamente al empeño por hacerlo de forma congruente y sistemática. En todo caso, tales restricciones deben aplicarse de modo no discriminatorio (véase, en este sentido, la sentencia de 8 de septiembre de 2009, Liga Portuguesa de Futebol Profissional y Bwin International, C-42/07, Rec. p. I-7633, apartados 59 a 61 y jurisprudencia citada) $»^{28}$.

Tras lo apuntado podemos añadir que estos principios de buena regulación también han sido expresamente impuestos para la legislación en materia de viviendas de uso turístico de una manera muy contundente en la sentencia del Tribunal Supremo número 26/2019, de 15 de enero, exigiendo los principios de necesidad proporcionalidad y no discriminación al enjuiciar la zonificación Canarias que se consideró sustentada, ante la falta de rigor, sobre una falacia ${ }^{29}$.

28 Apartado 22.

29 Así en el F.J Tercero se afirma: «El primer argumento no es sino una falacia, puesto que las zonas turísticas se establecen sobre territorios en los que previamente pueden haberse implantado usos residenciales. La especialización de usos según zonas que tratan de promover las distintas leyes en materia turística - ley 6/2009, de 6 de mayo (LCAN 2009, 184), ley 2/2013, de 29 de mayo - no es sino una aspiración, pero dista mucho de ser una realidad.

El segundo argumento no puede ser valorado de mejor manera, puesto que decir que la normativa turística exige que los hoteles de ciudad se sitúen en las ciudades, o que los alojamientos de turismo rural se emplacen en el campo, es un argumento inconsistente. Lo que sucede es que se exigen unos estándares de calidad distintos a los establecimientos alojativos que se encuentren en las ciudades o en el campo. No se establece una limitación al establecimiento de alojamientos turísticos en determinadas zonas.

La Ley de turismo de Canarias no habilita, por tanto, al reglamento a establecer una modalidad de alojamiento turístico que únicamente pueda ser desempeñada fuera de las zonas turísticas. Lo que se contempla es que determinadas ofertas de turismo alojativo sean sometidas a estándares menos exigentes por razón de encontrarse fuera de las zonas turísticas.

Así las cosas, excluir la oferta de viviendas vacacionales de las zonas turísticas o de aquellas de uso mixto, precisamente donde se tratan de localizar predominantemente los usos turísticos, carece de cobertura legal en la Ley de turismo de Canarias. 
No es la primera ni única vez que se judicializa la normativa turística canarias $^{30}$ exigiendo cumplir con los principios de buena regulación o bien atender con propiedad las razones imperiosas de interés general como interpela el TS en su sentencia 1756/2018, 12 de diciembre de 2018, recurso 4959/2017 al indicar: «Debe señalarse al respecto que, como se puso de relieve en el acto de la vista celebrado ante esta Sala, la única justificación que se dio acerca de conveniencia de formalizar la exclusión de la oferta de viviendas vacacionales ubicadas en zonas turísticas fue la de que obedecía a meras razones de carácter económico (que las viviendas vacacionales no compitan con el resto de establecimientos alojativos turísticos hoteleros u extrahoteleros, para lo que sería necesario que no se ubiquen en la mismas zonas), lo que entendemos no puede incardinarse en ninguna de las razones imperiosas de interés general comprendidas en el artículo 3.11 de la Ley 17/2009, de 23 de noviembre, sobre el libre acceso a las actividades de servicios y su ejercicio, al que se remite el artículo 5 de la Ley 20/2013, de 9 de diciembre, de garantía de la unidad de mercado.

La invocación ulterior, en fase procesal, de razones imperiosas de interés general vinculadas a la ordenación del territorio y al urbanismo, resulta insuficiente, en la medida que no estimamos convincente la explicación ofrecida respecto que la prohibición contemplada referida a la comercialización de viviendas vacacionales en zonas turísticas tenga como finalidad preservar el uso racional de suelos reservados a desarrollos turísticos, según la planificación del territorio» ${ }^{31}$.

El reglamento infringe claramente la libertad de empresa (artículo $38 \mathrm{CE}$ ) y la libertad de prestación de servicios (Directiva 2006/123/CE, de 12 de diciembre) limitando la oferta turística sin justificación suficiente. No tiene sentido alguno que la oferta de viviendas vacacionales se trate de excluir de aquellos ámbitos donde debe localizarse preferentemente la actividad turística. La única explicación plausible a esta cortapisa es que con ello se trata de favorecer la oferta de productos alojativos turísticos tradicionales implantados mayoritariamente en estas zonas turísticas, vulnerando con ello la libre competencia en la prestación de servicios.»

${ }^{30}$ Una crítica desde el derecho administrativo en Rodríguez González, M.P. «Algunos aspectos cuestionables de la regulación actual de las viviendas vacacionales en Canarias, que evidencia la necesidad de su revisión» en AA.VV. (Directoras González Cabrera I./Rodríguez M.P.) Las viviendas vacacionales: entre la economía colaborativa ...ob.cit., págs. 102 y ss.

31 Sobre el análisis de la normativa urbanística a la hora de fijar los usos turísticos del suelo rústico canario concluye Sarmiento que «la articulación especial de los instrumentos de ordenación supone una inserción de la ordenación turística en la ordenación territorial, y una "puesta en valor" del suelo rústico con estas finalidades». Hay una modulación de los Planes Insulares de Ordenación, que incorpora determinaciones específicas para las islas verdes, y sobre todo una erección de una figura muy peculiar, incluso en su denominación: los instrumentos de planificación singular turística, que pueden aplicarse en cual- 
El concepto de razones imperiosas de interés general, al que hace referencia, la Directiva 2006/123 y la Ley 17/2009, de 23 de noviembre, sobre el libre acceso a las actividades de servicios y su ejercicio, abarca, entre otros aspectos, la protección del medio ambiente y del entorno urbano, así como la planificación urbana y rural." 32

Resulta muy esclarecedora le sentencia del Tribunal Superior de justicia de Castilla y León (sala de lo Contencioso administrativo sección primera Valladolid), n. ${ }^{\circ} 86 / 2018$, de 2 de febrero de 2018 cuando indica: "Como vimos más arriba, la normativa estatal y comunitaria, considera que la finalidad de protección de los derechos, la seguridad y la salud de consumidores u usuarios turísticos responde a razones de interés general y puede justificar, en principio, que se establezcan límites y restricciones al ejercicio de la actividad comercial, siempre y cuando sean necesarias y proporcionales para alcanzar tal fin, por lo que es desde esta finalidad desde la que debemos analizar cada uno de los preceptos impugnados, para en definitiva determinarse si en los mismo se imponen restricciones que sean necesarias y proporcionales para proteger a los consumidores y usuarios de los servicios de alojamiento turístico. $\rangle^{33}$

A esa potestad de ordenación de los recursos turísticos a través de planes Territoriales sectoriales reconocido en el artículo 51.g de la ley de turismo del País Vasco la Autoridad de competencia vasca recordó en su informe que a la hora de diseñar los concretos instrumentos de planificación turística debe realizarse el análisis previo de necesidad proporcionalidad y mínima distorsión. Esta exigencia queda recogida en diversos apartados del mismo, siendo destacable el punto 52 de dicho informe por indicar que deberán evitarse

quier clase y categoría de suelo, contener o no ordenación, ser promovidos por iniciativa pública o privada y realizar operaciones de gran entidad territorial, que condicionan - en realidad, se imponen - al planeamiento, pues es obligado integrar sus determinaciones en el planeamiento territorial y urbanístico que resulte afectado (artículo 10.6, Ley 14/2019, de 25 de abril, de ordenación territorial de la actividad turística en las islas de El Hierro, La Gomera y La Palma.); se configuran teniendo en cuenta los Proyectos de interés insular o autonómico, pero tienen incluso más potencia, pues no se aprecian los límites que en relación con estos prevé el artículo 123.4 de la Ley 4/2017, de 13 de julio, del Suelo y de los Espacios Naturales Protegidos de Canarias. Sarmiento Acosta, M.J., «Las normas especiales y ampliatorias de los usos en el suelo rústico por razón del turismo en las "Islas Verdes" de Canarias», Revista Aranzadi de Urbanismo y Edificación n. ${ }^{\circ}$ 44/2020, parte Estudios (consulta online).

32 F.J Segundo.

${ }^{33}$ F.J. Tercero. Esta sentencia resuelve el recurso contencioso administrativo interpuesto por la CNMC al decreto 3/2017, de 16 de febrero, por el que se regulan los establecimientos de alojamiento en la modalidad de vivienda de uso turístico en la Comunidad de Castilla y León que impone restricciones de diversa naturaleza a las viviendas de uso turístico y son analizadas estimando algunas de las argumentaciones previas de la CNMC. 
restricciones en los usos del suelo como, por ejemplo, el establecimiento de distancias mínimas entre tipologías de uso o entre competidores o el número máximo de establecimientos de determinadas características cualquier restricción en el uso del suelo debería estar justificada en la consecución de un objetivo de interés general y realizarse a través de una medida proporcionada y no discriminatoria ${ }^{34}$.

Actualmente uno de los grandes problemas que afrontan las normativas turísticas es la intervención de las corporaciones locales y su tendencia a regular sobre la premisa de que la cesión de uso vacacional de una vivienda es asimilable al uso terciario hotelero. Por ello hay una tendencia a aplicar por analogía el citado uso terciario cuando la vivienda sigue manteniendo un uso residencial que la caracteriza y no se pierde (corrientes a favor de lo contrario sostienen que las viviendas vacacionales no ofrecen alojamiento estable y permanente, sino temporal) ${ }^{35}$; El escenario se complica pues en muchas ocasiones los planes generales y las normativas básicas originarias no lo han tenido en cuenta ya que no han previsto expresamente el uso de vivienda turística $^{36}$. Ello nos lleva a recordar que la interpretación de las normas debe atender a los principios de derecho, la relación con el contexto, los antecedentes históricos y legislativos y la realidad social del tiempo en que han de ser aplicadas atendiendo al espíritu de la norma. A pesar de ello las interpretaciones y revisiones recientes van en contra del principio favor libertatis $^{37}$ que impone que los actos de intervención deberán ser los menos restrictivos

${ }^{34}$ Punto 52 página 28 del Informe al anteproyecto de ley de turismo de Euskadi $<$ http:// www.competencia.euskadi.eus/contenidos/informacion/informes/es_informes/Informe\%20al\%20Anteproyecto\%20de\%20Ley\%20de\%20Turismo\%20de\%20Euskadi.pdf>

${ }_{35}$ En este sentido se pronuncia la Sentencia del TSJ de Asturias de 19 de noviembre de 2018 que sustenta su criterio sobre las siguientes premisas: Dentro de la misma categoría, se encontraría el uso residencial continuo y uso residencial turístico; Distinta naturaleza, funcionalidad y régimen jurídico de las VUT con respecto a los establecimientos hoteleros; La vivienda que se destina a alojamiento turístico temporal no pierde por ese hecho su carácter residencial; La consideración de alojamiento turístico no excluiría la posible consideración de domicilio a efectos de recabarse autorización judicial para entrar en el mismo. Sobre entradas en establecimientos de alojamiento devien fundamental lo establecido en STC 10/2002, 17 de enero de 2002 (BOE n. ${ }^{\circ} 34$ de 8 de febrero de 2002) caso Hotel Macarena Sol Sevilla, que analiza la derogación del artículo 557 de la LEcrim, que permitía la entrada y registros de las habitaciones en hoteles, hostales y alojamientos turísticos.

${ }^{36}$ Comentando los debates sobre la configuración y conveniencia de ese uso terciario García Rubio, F. «El papel de la administración ante el turismo de plataformas» en AA.VV (director Franch Fluxà, J.) Economía de plataformas: retos y normativa, Atelier, Barcelona, 2020, págs. 101 y ss.

37 Muy a menudo se olvida una premisa que es «de manual»: «la libertad es la regla; la limitación es, en cambio, la excepción, que, como tal, han de interpretar restrictivamen- 
de la libertad individual. Es notorio que dicho principio es común y basilar y se encuentra en el artículo 84 de la Ley 7/1985, de 2 de abril reguladora de las bases del régimen local y también en el ya citado artículo 4 de la Ley 40/2015 de 1 de octubre del régimen jurídico del sector público.

En cuanto al test exigido por el principio de buena regulación debe recordarse que no serán las patronales ni los afectados los que deben soportar la carga de la prueba para justificar su disconformidad, sino que son las propias administraciones las que deben probar que la necesidad y proporcionalidad de sus medidas quedan debidamente justificadas y motivadas. Al respecto podemos mencionar la Sentencia del TJUE, de 11 de diciembre de 2014 (asunto C-576/13, Comisión contra Reino de España) que indica: «Según jurisprudencia reiterada del Tribunal de Justicia, las restricciones a la libertad de establecimiento que sean aplicables sin discriminación por razón de nacionalidad pueden estar justificadas por razones imperiosas de interés general, siempre que sean adecuadas para garantizar la realización del objetivo que persiguen y no vayan más allá de lo que es necesario para alcanzar dicho objetivo (véanse, entre otras, las sentencias Comisión/Austria, C 356/08, EU:C:2009:401, apartado 42, y Comisión/Francia, EU:C:2010:772, apartado 50).

A este respecto, y contrariamente a lo que mantiene el Reino de España, no corresponde a la Comisión sino a las autoridades nacionales competentes demostrar, por un lado, que su normativa es necesaria para alcanzar el objetivo que persigue, $y$, por otro lado, que se ajusta al principio de proporcionalidad (véanse, en este sentido, las sentencias Comisión/Finlandia, C 54/05, EU:C:2007:168, apartado 39, y Comisión/Portugal, C 438/08, EU:C:2009:651, apartado 47).»

La primacía del derecho comunitario debe quedar muy clara tal como interpretó el Tribunal Constitucional en la Sentencia 145/2012 de 2 de julio que ratificó la primacía del Derecho comunitario como técnica o principio normativo destinado a asegurar su efectividad, reconociendo esa primacía de las normas del ordenamiento comunitario, originario y derivado, sobre el interno.

Dichas medidas urbanísticas — que a menudo consideramos, como mínimo, restrictivas - contienen en su esencia criterios de planificación económica que persiguen una regulación de la oferta del alojamiento turístico ${ }^{38}$,

te». Vid. García de Enterría, E y Fernández, T.R. Curso de Derecho Administrativo, Civitas, Thomson Reuters, Madrid, volumen II, 15. a ed., 2017, pág. 142.

${ }_{38}$ Atendiendo al contenido de la sentencia del Tribunal de Justicia la Unión Europea de 24 de marzo de 2011, Comisión Europea vs Reino de España (asunto C-400/08) Román apunta sobre determinados planes especiales que han sido controvertidos: «en mi opinión parece claro que este tipo de planes no responden a la finalidad propia de la planificación urbana, cual es la ordenación arquitectónica de los espacios de la ciudad y las condiciones para su transformación y desarrollo, sino que contiene importantes implicaciones económicas que trascienden a la materia urbanística. La única finalidad de estos planes es regular una determinada actividad económica, por lo que su naturaleza como instrumento urbanístico 
con lo que podría criticarse que los poderes públicos han obviado que tanto nuestro Tribunal Supremo como Tribunal de Justicia Europeo sostienen que no es admisible una planificación de la oferta comercial fundada en factores económicos o comerciales.

Si bien no puede negarse, como ocurre en cualquier otra actividad económica que el turismo pueda presentar externalidades negativas ${ }^{39}$; de este modo, es fundamental tener claro - máxime si hablásemos de prohibiciones radicales- que los medios a disposición de la administración para conseguir determinados objetivos deben provocar la menor distorsión sobre el mercado y la competencia ${ }^{40}$. En otras palabras, nuevamente debemos reiterar que la administración debe optar por la medida menos gravosa, que implica que esta satisface los requisitos de idoneidad y de menor intervención para el fin perseguido.

\section{LA NORMATIVA DE VUT COMO EJEMPLO DE LIMITACIÓN DE LA COMPETENCIA EN EL ÁMBITO TURÍSTICO}

Una de las funciones de los poderes públicos es velar por el desarrollo de una competencia efectiva que permita la entrada de nuevos operadores. Por

debe ser puesto en entredicho a los efectos de su exclusión de la Directiva de Servicios, por más que su existencia pueda estar justificada para sus redactores en razones como la supuesta incompatibilidad relativa a los usos del suelo entre la actividad de alojamiento turístico y el uso residencial de las viviendas, o en la protección del derecho fundamental a una vivienda digna». Vid. Román Márquez, A. «Planificación urbanística del turismo: la regulación de las viviendas de uso turístico en Madrid y Barcelona». Revista De Estudios De La Administración Local Y Autonómica, (10), 2018, pág. 27 https://doi.org/10.24965/reala.v0i10.10566

39 Sobre las distintas externalidades que genera la comercialización de estancias en las plataformas vid. Hinojo González, P. «La promoción de la competencia en el turismo colaborativo en la era digital» en AA.VV (director Franch Fluxà, J.) Economía de plataformas: retos y normativa, Atelier, Barcelona, 2020, págs. 149 y ss.

${ }^{40}$ Como indica el TSJ de las Illes Balears en su Sentencia n. ${ }^{\circ} 486 / 2021$, de 10 de septiembre de 2021 respecto a la zonificación de Palma donde se prohíbe la comercialización de estancias en viviendas plurifamiliares: «Las finalidades públicas perseguidas pueden obtenerse a través de medios menos radicales, algunos de ellos ya positivizados. La prohibición, lógicamente, constituye la última de las soluciones posibles a los efectos nocivos que la Administración demandada trata de evitar y atajar. El libre ejercicio de la actividad turística debe conjugarse con los intereses generales, y en esta interconexión pueden adoptarse decisiones administrativas que deben ser proporcionales, idóneas y necesarias para la colectividad. La prohibición absoluta de la comercialización de ETH en edificios plurifamiliares no aparece como ponderada con las finalidades alegadas por el Ayuntamiento, el cual, bajo el escudo de la normativa comunitaria, estatal y autonómica, ostenta competencias en materia de protección del medioambiente, la convivencia, la ordenación de su territorio y el diseño del mismo, y en ejercicio de estas atribuciones puede hacer uso de sus potestades, entre ellas, la reglamentaria destinada a regular un marco de gestión de las actividades económicas que repercuten en tales ámbitos de interés general.» (F.J. Séptimo). 
lo tanto, la administración debe actuar en el mercado siempre que sea acreditada la existencia de fallos de mercado y que estos puedan afectar a razones imperiosas de interés general. Gracias a la competencia se permite reasignar los recursos productivos a favor de los operadores y técnicas más eficientes ${ }^{41}$. La eficiencia productiva se traduce en un mayor beneficio de los consumidores en forma de precios o de un aumento de la cantidad y calidad de los productos provocando un mayor bienestar colectivo. La protección del mercado conforme al artículo 38 corresponde a los poderes públicos que velarán por su garantía y protección. Para ello resulta basilar la imposición impuesta en el artículo 1 de la Ley 15/2007, de 3 de julio, de defensa de la competencia, que con carácter general «prohíbe todo acuerdo, decisión o recomendación colectiva, o práctica concertada o conscientemente paralela, que tenga por objeto, produzca o pueda producir el efecto de impedir, restringir o falsear la competencia en todo o parte del mercado nacional».

Ello impone, según hemos explicado, que en la elaboración y aprobación de normas - a cualquier nivel de producción normativa - las administraciones deban tener en cuenta, junto a otros intereses, la necesidad de garantizar el funcionamiento competitivo de los mercados y, para ello, se establecen los principios de regulación económica efectiva. Por lo tanto, debe criticarse que sea el propio sector público el que a través de sus potestades regulatorias introduzca restricciones injustificadas a la competencia.

En el ámbito de las viviendas vacacionales se ha producido un giro radical de la competencia desleal hacia la defensa y promoción de la competencia. Los primeros debates y pasos normativos se estructuraron a partir de la erradicación de la competencia desleal y el intrusismo que ilustra la reforma de la LAU en $2013^{42}$. A partir de este momento fueron añadiéndose otros elementos para la intervención como, por ejemplo, la protección de los consumidores mediante unos mínimos de calidad y seguridad y que ha propiciado la existencia y creación un registro de actividades turísticas y un censo de viviendas turísticas como ocurre en Andalucía o el Principado de Asturias o Madrid $^{43}$.

${ }^{41}$ En este sentido y analizando la trascendencia social y económica de la promoción de la competencia. Canedo Arrillaga, M. P. «Poderes públicos y competencia. En busca del efecto útil del Derecho de competencia», Cuadernos de derecho transnacional, Vol. 12, n. ${ }^{\circ}$ 2, 2020, págs. 226-253.

${ }_{42}$ Véase la exposición de motivos y el artículo 5 apartado e) tras la reforma por Ley 4/2013, de 4 de junio, de flexibilización y fomento del mercado de alquiler de viviendas. Para más detalle González Jiménez, P. M. «La oferta de viviendas de uso turístico a través de plataformas colaborativas: reflexiones desde el derecho de la competencia desleal», en Revista de Estudios Europeos, n. ${ }^{\circ}$ 70, julio-diciembre, 2017, págs. 111-126.

${ }^{43}$ Sobre las principales restricciones existentes en Madrid y Barcelona, vid. Vid. Román Márquez, A. «Planificación urbanística del turismo: la regulación...», ob. cit. pág. 36 y ss. 
La Comisión Nacional de los Mercados y la Competencia ${ }^{44}$, en adelante CNMC, ya en marzo de 2016, tras el trabajo que establece las Conclusiones preliminares sobre los nuevos modelos de prestación de servicios y la economía colaborativa propone una serie de recomendaciones que, lamentablemente, son aplicables a la reacción normativa que en los últimos años están consolidando y aplicando las corporaciones locales y ayuntamientos o las propias $\mathrm{CCAA}^{45}$. Entre estas recomendaciones podemos destacar: la aplicación de los principios de regulación económica eficiente por parte de las administraciones públicas en la regulación sectorial y horizontal (como pueden ser impuestos o cotizaciones sociales), mayores libertades en el ejercicio de la actividad de alquiler de las viviendas de uso turístico, seguimiento estadístico de la modalidad de alojamiento en viviendas de uso turístico, mayor libertad de acceso al mercado de viviendas de uso turístico.

En este documento subraya que es importante actuar solamente cuando exista un fallo de mercado que requiera intervención pública para salvar una razón imperiosa de interés general y en el caso de que dicha intervención esté justificada se someta a los principios de necesidad y proporcionalidad. Las medidas que dificulten la mayor eficiencia del mercado son contrarias al interés general y deben ser removidas para incrementar el bienestar social (obviamente, es probable que este tipo de medidas incorporen restricciones de entrada o afecten al ejercicio de una determinada actividad).

En el Informe de la CNMC sobre viviendas turísticas (2018) se resalta que la zonificación es una restricción que consiste en establecer limitaciones o incluso prohibir la implantación de viviendas de uso turístico en determinadas zonas o barrios de la ciudad situados en el centro histórico o aledaños y caracterizados por un número elevado de alojamientos turísticos por la afluencia de turistas en esas zonas el hecho que se impongan barreras de entrada a nuevos operadores al mercado en las zonas turísticas refuerza el poder de mercado en los operadores inconvenientes, es decir, ya instalados (la oferta hotelera). Debe quedar muy claro que cuando se pone una barrera

${ }^{44}$ Sobre las funciones y actuaciones de la CNMC (impugnación e informes económicos en legitimación activa) puede consultarse el capítulo (centrado en el sector transporte) elaborado por quien fuera Director del Departamento de Promoción de la Competencia Antonio Maudes. Vid. Maudes, A. «La aplicación de los principios de regulación económica eficiente al transporte colaborativo. El papel de la CNMC» en AA.VV. (editores Boix A./De la Encarnación A.M./Doménech G.) La regulación del transporte colaborativo, Thomson Reuters Aranzadi, Cizur Menor, 2017, págs.45 y ss.

${ }^{45}$ Han quedado completamente superados los debates sobre la regulación o no de lo que en su momento se calificaba como economía colaborativa y que actualmente engloba gran parte de esta comercialización onerosa de estancias en viviendas. Para más detalle vid. AA.VV. (directores Alonso Sánchez, R. y Valero Torrijos, J.) Retos jurídicos de la economía colaborativa en el contexto digital, Thomson Reuters, Aranzadi, Cizur Menor, 2017. 
de entrada por parte de la administración el mercado se resiente ya que ello implica precios más elevados para los consumidores menores incentivos a la eficiencia, la inversión, la innovación, la calidad del servicio y todo ello, al final, repercute en la calidad y la competitividad del destino turístico en el que se aplican estas medidas ${ }^{46}$.

Muy vinculado al tema de la priorización de derechos o intereses - tanto en juego como contrapuestos - debemos tener en cuenta el ya citado Informe 19 de julio de 2018 CNMC establece claramente las externalidades positivas atribuibles a las VUT: efectos pro competitivos derivados del incremento de la oferta que provoca una reducción del precio medio del mercado y mejora de la calidad ofertada; incremento de la variedad de opciones de alojamiento turístico disponibles; mayor información disponible para los usuarios debido a las plataformas y a los sistemas de valoración que incorporan; generación de rentas a favor de particulares permitiéndose la democratización y acceso a la actividad turística como fuente de ingresos; modernización de barrios del centro de las ciudades por adecuación y mantenimiento de las viviendas para poder ser ofertadas para uso turístico; trazabilidad y mayor transparencia en las transacciones económicas fruto de los medios de pago y el uso de las plataformas de intercambio.

Como hemos expuesto, una de las cuestiones más controvertidas y que ha generado diversas actuaciones de la CNMC es la relación entre las normas urbanísticas y el acceso a la actividad ${ }^{47}$. A pesar de la aparente exclusión de las normas urbanísticas del ámbito de aplicación de la Directiva de servicios se extiende el ámbito de aplicación de la directiva de servicios a cualquier instrumento formalmente urbanístico que desde un punto de vista material contenga una regulación económica que afecta directamente al acceso económica que afecta directamente al acceso y ejercicio de actividades de carácter económico que deben realizarse en competencia y que por tanto, no están excluidos de la Directiva de servicios ${ }^{48}$.

Finalmente conviene indicar que las restricciones se han centrado y concretado principalmente en determinadas tipologías de alojamiento ${ }^{49}$. En el

46 Vid. E/CNMC/003/18: Estudio sobre viviendas de uso turístico en la web de la CNMC $<$ https://www.cnmc.es/expedientes/ecnmc00318> especialmente en sus páginas 50 a 56 .

${ }^{47}$ Uno de los últimos ejemplos es Informe económico sobre las restricciones a la competencia incluidas en el plan especial de hospedaje del Ayuntamiento de Madrid -LA/05/2019 que ha sido estimado parcialmente por el TSJ de Madrid en 2021. Ambos se pueden consultar en $<$ https://www.cnmc.es/expedientes/la052019>.

${ }_{48}$ Conclusiones que se extraen de la lectura del considerando 9 de la Directiva y lo establecido en el punto 2.3.2 del Manual sobre la transposición de la directiva de servicios en la página 15 de este Manual. < https://op.europa.eu/es/publication-detail/-/publication/ a4987fe6-d74b-4f4f-8539-b80297d29715>

49 Siguiendo la sistematización realizada por la CNMC podríamos diferenciar entre: a) restricciones especialmente graves como la prohibición de licencias para viviendas 
caso de las (grandes) ciudades por ser la más común y extendida la discusión se ha centrado en los pisos turísticos que radican en edificios plurifamiliares, es decir, fincas sometidas al régimen de propiedad horizontal. Su comercialización ha sido constantemente debatida y la razón principal debe atender a un criterio de igualdad ya que ha sido limitada o prohibida desde el momento inicial en el que se desarrolla y aprueba la regulación de esta materia. La expulsión del mercado de las viviendas de tipología plurifamiliar, ya sea de manera radical o bien limitada a determinadas plantas o por algunos requisitos de morfología edificatoria (entrada independiente) comportan una restricción adicional, probablemente insalvable, para los nuevos operadores que quieran ofertar una vivienda residencial para estancias turísticas en edificios ${ }^{50}$.

A modo de preámbulo del siguiente apartado debemos citar un informe de la CNMC previo a la expansión de las viviendas vacacionales donde se abordaba la zonificación del suelo. Ya en el Informe E-2012-01 de la CNC Problemas de competencia en el mercado del suelo en España se extraen las siguientes conclusiones sobre la zonificación:

a) No constituye un mecanismo suficientemente eficaz para corregir determinadas externalidades.

b) Puede llevar a una provisión ineficiente de bienes públicos.

c) Limita de forma considerable la competencia en el mercado del suelo.

\section{LA ZONIFICACIÓN TURÍSTICA COMO TÉCNICA RESTRICTIVA}

Antes de centrarnos en los aspectos más turísticos conviene recordar que existe una conexión directa entre la zonificación y el derecho a la propiedad

turísticas, la aplicación de moratorias y zonificación de ciudades, el establecimiento de cupos por zonas, la prohibición de alquilar habitaciones, la limitación de la duración de la estancia, el establecimiento de tamaños mínimos o la regulación de los precios de los alquileres; b) requisitos y obligaciones que suponen una carga para los titulares de viviendas, tales como las exigencias de equipamiento y servicios mínimos - climatización, wifi, asistencia telefónica o placas distintivas - , los regímenes de autorización previa o la exigencia de comunicación de precios a la Administración.

${ }_{50}$ Como ocurre en el Plan Especial de Hospedaje del Ayuntamiento de Madrid validado por el TSJ de Madrid en Sentencia n. ${ }^{\circ}$ 10/2021, de 14 de enero de 2021, o en la aprobación provisional de la modificación puntual del Plan General de Ordenación Urbana de San Sebastián 25 de marzo de 2019 publicada en el Boletín Oficial de Gipuzkoa, finalmente rechazada por el TS mediante fechada el 21 de enero, contra el recurso de casación 2250/20, referido a la 'Aprobación definitiva de la ordenanza reguladora del uso de vivienda turística y de alquiler de habitaciones de vivienda habitual para uso turístico'. 
en el art. 11.1 del RDL 7/2015, de 30 de octubre, por el que se aprueba el texto refundido de la Ley de Suelo y Rehabilitación Urbana ${ }^{51}$ : El régimen urbanístico de la propiedad del suelo es estatutario y resulta de su vinculación a concretos destinos, en los términos dispuestos por la legislación sobre ordenación territorial y urbanistica."

El binomio urbanismo-turismo es una tendencia que queda patente en normativas turísticas como las de las Islas Baleares que se remiten a las normas de ordenación territorial. Así el artículo 5 establece que conforme a la Ley 14/2000, de 21 de diciembre, «los planes de intervención en ámbitos turísticos (PIAT) son planes directores sectoriales cuyo objeto es el de regular el planeamiento, la ejecución y la gestión de los sistemas generales de las infraestructuras, los equipamientos, los servicios y las actividades de explotación de recursos en el ámbito de la ordenación turística. $\rangle^{52}$

Para justificar el interés general de la actuación y políticas urbanísticas se entiende que esta planificación se destina a garantizar la calidad de vida de la ciudadanía y también el desarrollo sostenible de las urbes. Esos ejes estructurales se insertan modernamente dentro de una concepción de desarrollo sostenible que se manifiesta en hitos como los establecidos en el artículo 3.3 a) del Real Decreto Legislativo 7/2015, de 30 de octubre, por el que se aprueba el texto refundido de la Ley de Suelo y Rehabilitación Urbana cuando se manifiesta que los poderes públicos «posibilitarán el uso residencial en viviendas constitutivas de domicilio habitual en un contexto urbano seguro, salubre, accesible universalmente, de calidad adecuada e integrado socialmente, provisto del equipamiento, los servicios, los materiales y productos que eliminen o, en todo caso, minimicen, por aplicación de la mejor tecnología disponible en el mercado a precio razonable, las emisiones contaminantes y de gases de efecto invernadero, el consumo de agua, energía y la producción de residuos, y mejoren su gestión». En esta misma norma marco también se impone que el suelo vinculado a un uso residencial por la ordenación territorial y urbanística esté al servicio de la efectividad del derecho a disfrutar de una vivienda digna y adecuada en los términos que disponga la legislación en la materia ${ }^{53}$.

${ }^{51}$ Concretamente se afirma: 1 . El régimen urbanístico de la propiedad del suelo es estatutario y resulta de su vinculación a concretos destinos, en los términos dispuestos por la legislación sobre ordenación territorial y urbanística.

52 En la Ley 14/2000 de ordenación territorial balear los Planes Directores Sectoriales son uno de los tipos de instrumentos contemplados en el artículo 3 y se definen en el artículo 11 (naturaleza y clases) como aquellos instrumentos de ordenación y planificación que tienen por objete regular la incidencia territoriales de las diferentes políticas sectoriales.

${ }_{53}$ El art. 3.4 del Texto refundido de la Ley de Suelo y Rehabilitación Urbana (TRLSRU) exige la necesidad de garantizar que el suelo vinculado a un uso residencial se ponga al servicio de la efectividad del derecho a disfrutar de una vivienda digna y adecuada. 
La expresión turistificación (de las ciudades) ha venido a englobar todas las externalidades y efectos negativos que puede generar la actividad turística sobre todo cuando se consolida en entornos urbanos frente a las zonas costeras destinadas tradicionalmente al turismo ${ }^{54}$. Entre los argumentos más manidos a la hora de desprestigiar la actividad turística en términos de sostenibilidad ambiental suelen alegarse los consumos de agua y la generación de residuos, entendiendo que son superiores en el caso de los turistas frente a los residentes sobre la premisa de que estos no son tarifados o cobrados aparte y son asumidos con independencia del volumen por los empresarios turísticos de alojamiento.

La expulsión de la población residente, fenómeno que se ha denominado gentrificación, y la dificultad creciente que tiene para acceder a la vivienda es considerado uno de los problemas de primer orden que se debe afrontar pues se entiende que el destino turístico de las viviendas afecta el equilibrio del mercado de la vivienda, que deriva en un escenario de tensión económica y financiera por el hecho de ser un activo económico y estar sometido la burbuja inmobiliaria y la especulación ${ }^{55}$. Si en la década anterior el acceso a los préstamos hipotecarios pudo afectar seriamente a este mercado ahora las maldades se sitúan en alquiler turístico ya que el parque de viviendas y la demanda residencial se verían afectados por dicha comercialización.

Respecto al alcance de la propiedad privada se discute si este es un derecho potencialmente ilimitado o bien un derecho qué debe entenderse sometido

${ }^{54}$ Boix Palop, A. «Economía colaborativa para el desarrollo local». En M. R. Alonso Ibáñez (dir.), La sostenibilidad socioeconómica de las ciudades: estudios jurídicos, Tirant lo Blanch, 2018, pág. 382 y ss.

${ }_{55}$ Se ha convertido en un hito fundamental sobre este aspecto la Sentencia del Tribunal de Justicia (Gran Sala) de 22 de septiembre de 2020 Cali Apartments SCI y HX contra Procureur général près la cour d'appel de Paris y Ville de Paris (asuntos acumulados C-724 y 728718). De manera contundente el apartado 75 expresa: «Habida cuenta de las anteriores consideraciones, procede responder a las cuestiones prejudiciales tercera y cuarta que el artículo 9, apartado 1, letras b) y c), de la Directiva 2006/123 debe interpretarse en el sentido de que una normativa nacional que, en aras de garantizar una oferta suficiente de viviendas destinadas al arrendamiento de larga duración a precios asequibles, somete determinadas actividades de arrendamiento a cambio de una remuneración de inmuebles amueblados destinados a vivienda a clientes de paso que no fijan en ellos su domicilio, efectuadas de forma reiterada y durante breves períodos de tiempo, a un régimen de autorización previa aplicable en determinados municipios en los que la tensión sobre los arrendamientos es particularmente acusada está justificada por una razón imperiosa de interés general como la lucha contra la escasez de viviendas destinadas al arrendamiento y es proporcionada al objetivo perseguido, dado que este no puede alcanzarse con una medida menos restrictiva, en particular porque un control a posteriori se produciría demasiado tarde para ser realmente eficaz.» Sobre la idoneidad de las medidas adoptadas a tales efectos por los poderes públicos competentes (apartados 87 a 90). 
a la función social y desde el prisma del derecho público; por lo tanto, condicionado a los límites definidos por las normas urbanísticas y donde se utilizan como instrumento los planes de ordenación ${ }^{56}$. Las visiones más intervencionistas entienden que normas y planes no recortarían un derecho que inicialmente tiene una extensión mayor, sino que su cometido es definir cuál es la extensión de dicho derecho al precisar sus fronteras en función de la calificación y clasificación urbanística de las parcelas o los terrenos. Todo ello ampara que en nuestro sistema la planificación urbanística no da derecho a ningún tipo de indemnización que solo sería otorgable y reconocido en casos de ablación, recorte o privación de potestades previamente reconocidos con mayor extensión en una ley ${ }^{57}$.

Un ejemplo es Illes Balears donde la tipología de alojamiento objeto de este trabajo ha sido el eje para ordenar y solucionar las diversas problemáticas que la comercialización de estancias turísticas y que se entiende pueden colisionar con el derecho al domicilio libre de inmisiones, la planificación urbanística y la ordenación del territorio o la protección del medio ambiente. Sobre la comercialización de estancias en viviendas la Exposición de motivos de la Ley 6/2017, de 31 de julio, de modificación de la Ley 8/2012, de 19 de julio, del turismo de las Illes Balears, relativa a la comercialización de estancias turísticas en viviendas manifiesta: «Debe prestarse especial atención a las repercusiones que esta puede suponer sobre la configuración de los barrios o las zonas donde se concentre la oferta y en la convivencia pacífica en estos; además de la existencia de infraestructuras adecuadas, $\mathrm{y}$, a escala general, en el hecho de evitar una subida de los precios del arrendamiento o de la vivienda, así como en la falta de oferta de esta para la población residente.»

Estas técnicas de zonificación llevadas a cabo por las corporaciones locales tienen tres potenciales efectos que no se deberían olvidar ni obviar: a) una reducción de la oferta real de viviendas de uso turístico y una reducción de potenciales altas que debilita la competencia entre alojamientos turísticos b) consolida las modalidades de alojamiento tradicionales y ello lleva, por lo tanto, a coordinaciones anticompetitivas y a la rebaja de incentivos e inversiones para su mejora c) pérdida de todas las externalidades positivas derivadas de las viviendas vacacionales como puede ser el consumo en comercios de proximidad ${ }^{58}$.

${ }^{56}$ Los planes tienen una discrecionalidad amplia pero no ilimitada. De manera más extensa en Muñoz Guijosa, M.A, El derecho de propiedad del suelo. De la Constitución a la ordenación urbana, Civitas, Madrid, 2009.

${ }^{57}$ Sobre la discrecionalidad del planeamiento Desdentado Daroca, E. Discrecionalidad administrativa y planeamiento urbanístico, Aranzadi, Navarra, 1999

${ }^{58}$ Sobre los efectos positivos de las estancias en viviendas de uso turístico ya sea en gastos en restaurantes y comercios de proximidad como también de otro tipo de productos 
Nos sumamos a la opinión de que las viviendas vacacionales, o de uso turístico, solo deberían y solo pueden implantarse en un edificio destinado a vivienda, por lo tanto, en inmuebles calificados por el planeamiento urbanístico como de uso residencial. La Autoridad de competencia de la Comunidad Valenciana en un informe emitido el 22 de diciembre de 2016 (Informe CDC PROM 14/2015-Viviendas Turísticas) concluyó que el Ayuntamiento de Valencia no debe incluir las viviendas turísticas como uso terciario hotelero en la interpretación y aplicación de sus normas urbanísticas vigentes y menos aún debe modificar dichas normas está ese sentido. Dicho posicionamiento es coherente con lo previamente afirmado en la Sentencia n. ${ }^{\circ}$ 513/2013 del Tribunal Superior de Justicia de Madrid (Sección 2 Sala de lo Contencioso) donde se afirma: «las viviendas vacacionales turísticas son viviendas normales y corrientes $\rangle^{59}$.

El problema de fondo, mencionado anteriormente, es determinar si los mencionados planeamientos caen o no dentro del ámbito de la Directiva 2006/123/CE. La respuesta solo cabe caso por caso al analizar si las medidas plantean requisitos que afecten al acceso a una actividad de servicios o a su ejercicio o bien requisitos tales como normas relativas a la ordenación del territorio o/y de urbanismo que no regulan o afectan específicamente a la actividad del servicio, pero que tienen que ser respetadas por los prestadores en el ejercicio de su actividad económica, al igual que por los particulares en su capacidad privada. Así lo considera la STS, n. ${ }^{\circ} 779 / 2021$ de 2 de junio de 2021 donde expone que: «de lo actuado en vía administrativa solo se alcanza la preocupación del planificador por abordar la problemática de la viviendas de uso turístico en las ubicaciones de su razón habida cuenta de la preexistencia de los mismos y su concentración, defendiendo un modelo que según los casos detiene su atención en la manzana, en una zona o las zonas establecidas, sin que, además de ello, resulten mayores méritos que pudiesen hacer pensar en una ordenación que traspasase el ámbito de ordenación territorial de usos en que se ubica teniendo en cuenta las preexistencias que concurren ${ }^{60}$.

pueden consultarse los distintos barómetros del alquiler vacacional en España elaborados por la Universidad de Salamanca y Homeaway y que están disponibles en la página web de esta última plataforma dejando constancia, año tras año, del ascendente y positivo efecto de este fenómeno sobre las economías locales.

59 F.J. Segundo.

${ }^{60}$ F.J. Primero (in fine). En este fallo se considera la vulneración Directiva de Servicios en los siguientes mecanismos por el Plan especial de Barcelona para las viviendas turísticas: se vulnera por la imposición de los siguientes requisitos para el ejercicio de dicha actividad: una densidad máxima de viviendas de uso turístico limitadas a las existentes [artículo $\left.11.2^{\circ} . \mathrm{b}\right), 12.2^{\circ}$.c); $\left.13.2^{\circ} . \mathrm{c}\right)$ y $14.2^{\circ}$.c), en relación con el artículo 17]; el decrecimiento de habilitaciones de viviendas de uso turístico en determinadas zonas específicas [artículo $11.2^{\circ} . c$ ) y $14.2^{\circ}$.c)]; la prohibición de implantar viviendas de uso turístico en entidades con usos de viviendas a fecha 1 de julio de 2015 [artículos $7.1^{\circ}$.d), 12.2 ${ }^{\circ}$.b) y 
Por lo tanto, lo que resulta relevante es la naturaleza de la regulación que contengan ese instrumento o normativa urbanística. Por lo tanto, si esta pudiera tener un carácter económico o comercial la directiva de servicios resultará de aplicación. En nuestra opinión cualquier plan especial, cualquier zonificación, contendrá una regulación específica económica si: a) determina qué tipo de viviendas pueden desarrollar la actividad propia de las viviendas de uso turístico (por ejemplo quede limitado a una concreta tipología); b) establezca o imponga una barrera de entrada al mercado totalmente injustificada que impida que los titulares de las viviendas pueden desarrollar una determinada actividad; c) que para la elaboración de dicha zonificación se tengan en cuenta razones económicas.

Tanto el Tribunal de Justicia de la Unión Europea como el Tribunal Supremo han confirmado que si bien los instrumentos de planificación urbanística se fundamentan en principios y legislación urbanísticas ello no impide que le sean de aplicación las normas europeas y nacionales relativas al libre acceso a la actividad y a su ejercicio cuando de estos instrumentos se deriven restricciones a estas libertades ${ }^{61}$.

Conviene destacar también por su influencia en posteriores fallos de la Sentencia del Tribunal de Justicia (Gran Sala) de 30 de enero de 2018 College van Burgemeester en Wethouders van de gemeente Amersfoort contra X BV y Visser Vastgoed Beleggingen BV contra Raad van de gemeente Appingedam (asuntos acumulados C-360/15 y C-31/16) ${ }^{62}$ en la que se declara la aplicabilidad de la directiva de servicios a normas de carácter urbanístico en la medida en que éstas tengan por objeto determinar zonas en las que se puede ejercer una actividad y se dirige a las personas que pretenden desarrollarlas. Este dilema se plantea en muchas de las medidas que se han adoptado en nuestro país con el fin de limitar la actividad turística a través del urbanismo ${ }^{63}$.

$13.2^{\circ}$.b) del Plan ] y en la fijación del índice del 1,18 por 100 de densidad máxima de viviendas de uso turístico por manzana en determinadas zonas [artículos $12.2^{\circ} . d$ ), $13.2^{\circ}$.d) y 16 del Plan Especial aprobado]

${ }^{61}$ Sentencia del Tribunal de Justicia de 4 de junio de 2002, Comisión de las Comunidades Europeas contra República Portuguesa (Asunto C-367/98) o Sentencia del Tribunal de Justicia (Sala Segunda) de 24 de marzo de 2011, Comisión Europea contra Reino de España (Asunto C-400/08).

${ }^{62}$ Analizada detenidamente por Fernández Torres, J.R «Planificación urbanística y Directiva de servicios. El Tribunal de Justicia de la Unión Europea arroja luz», Revista Aranzadi de Urbanismo y Edificación n. ${ }^{\circ}$ 42/2018, Tribuna, Parte Estudios, págs. 93-114.

${ }^{63}$ A modo de ejemplo la limitación de viviendas turísticas en áreas de la ciudad (áreas de exclusión) con la finalidad de compatibilizar el uso turístico con el espacio urbano y que ya han sido enjuiciadas por Tribunales Superiores de Justicia como las STSJ Catalunya 12 de junio de 2014 (Recurso 425/10) y 12 de junio de 2017 (Recurso 254/13); STSJ País Vasco 29 de enero de 2018. 
Dicho fallo consagra que la Directiva de servicios no es contraria a que el acceso a una actividad de servicios se sujete a límites de esta naturaleza, siempre que se cumplan las condiciones de no discriminación, necesidad y proporcionalidad. Por lo tanto, el objetivo de protección del entorno urbano puede constituir una razón imperiosa de interés general que justifique un límite territorial como el controvertido en el litigio principal ${ }^{64}$.

Consideramos fundamental reproducir en este punto lo que manera expresa se afirma en los apartados 123 y 124 del fallo ${ }^{65}$ :

«Por consiguiente, la Directiva 2006/123 no debe aplicarse a requisitos que no pueda considerarse que constituyen tales restricciones, puesto que no regulan específicamente ni afectan específicamente al acceso a una actividad de servicios o a su ejercicio, si bien deben ser respetados por los prestadores en el ejercicio de su actividad económica, al igual que por los particulares en su capacidad privada.

(124) Dicho esto, ha de considerarse que las normas controvertidas en el litigio principal, aunque, como se desprende de la resolución de remisión, tengan como finalidad preservar la habitabilidad del centro de la ciudad del municipio de Appingedam y evitar la existencia de locales desocupados en zona urbana en el marco de una política de ordenación del territorio, también tienen como objeto específico determinar las zonas geográficas en las que pueden implantarse ciertas actividades de comercio minorista. Así pues, se dirigen exclusivamente a las personas que pretenden desarrollar esas actividades en dichas zonas geográficas, con exclusión de los particulares en su capacidad privada. Por consiguiente, la Directiva 2006/123 no

${ }^{64}$ En este sentido también la Sentencia n. ${ }^{o} 292 / 2019$, de 11 de junio, de la Sala de lo Contencioso-Administrativo (Sección $2^{\mathrm{a}}$ ) del Tribunal Superior de Justicia del País Vasco (recurso 565/2018), que constituye una razón imperiosa de interés general la preservación del derecho a la vivienda de la población afectada por la ordenación así como la protección del entorno urbano.

${ }^{65}$ En las Conclusiones de 18 de mayo de 2017 el AG Szpunar indicó: «Sin embargo, el considerando 9 no se refleja en ninguna parte de la Directiva en el sentido de que se corresponda con una de las disposiciones (preceptivas). En consecuencia, los ámbitos enumerados en dicho considerando no quedan excluidos per se del ámbito de aplicación de la Directiva 2006/123 por el mero hecho de que se mencionen en dicho considerando. Por lo tanto, la Directiva no contiene un ángulo muerto en lo que se refiere a los planes urbanísticos.» (apartado 133).

«En cambio, el considerando 9 no implica que un plan urbanístico esté totalmente excluido del ámbito de aplicación de la Directiva. En efecto, es posible que el plan urbanístico afecte a los prestadores de servicios específicamente. Los límites territoriales (artículo 15, apartado 2) y las autorizaciones para las grandes superficies comerciales (considerando 47) están contempladas expresamente en la Directiva. Además, según lo entiendo, cualquier norma, con independencia de su origen, que tenga por efecto incrementar los costes de establecimiento de los prestadores de servicios, está comprendida en principio en el ámbito de aplicación de la Directiva 2006/123.» (apartado 137). 
debe aplicarse a requisitos que no pueda considerarse que constituyen tales restricciones, puesto que no regulan específicamente ni afectan específicamente al acceso a una actividad de servicios o a su ejercicio, si bien deben ser respetados por los prestadores en el ejercicio de su actividad económica, al igual que por los particulares en su capacidad privada.»»

En esta línea y acogiendo la doctrina sentada por la recién mencionada sentencia se ha pronunciado el Tribunal Supremo Tribunal Supremo (Sala de lo Contencioso-Administrativo, Sección 5 ${ }^{\mathrm{a}}$ ) Sentencia n. ${ }^{\circ}$ 2259/2016, de 19 octubre, al afirmar:

«Pese a que, como acabamos de señalar, la Directiva 2006/123 proclama que no se aplica respecto de las normas relativas a la ordenación del territorio, urbanismo y ordenación rural, resulta, que la propia Directiva enuncia entre las «razones imperiosas de interés general» que habilitan ciertos regímenes autorizatorios $-\mathrm{y}$, por ende, restricciones-, la protección del medio ambiente y del entorno urbano, incluida la planificación urbana y rural (considerandos 40 y 56). En este sentido, la Jurisprudencia del Tribunal de Justicia de las Comunidades Europeas ha establecido reiteradamente que todas las medidas nacionales, incluidas por tanto la ordenación del territorio y el urbanismo, que restrinjan el ejercicio de las libertades fundamentales garantizadas por el Tratado CE únicamente pueden justificarse si reúnen los siguiente cuatro requisitos:

a) aplicación de manera no discriminatoria,

b) que estén justificadas por razones imperiosas de interés general,

c) que sean adecuadas para garantizar la realización del objetivo que persiguen,

d) no vayan más allá de lo necesario.» ${ }^{66}$

El TS nos ha recordado recientemente que «cuando la regulación de la libertad de establecimiento de servicios se realiza directamente, como aquí sucede, por el planeamiento urbanístico, la aplicación de la normativa general en materia de libre prestación de servicios que se imponen tanto en la Directiva como en la Ley nacional, tiene la peculiaridad de que debe ser el mismo planeamiento el que debe contener las exigencias que se imponen, tanto para someter la actividad a la previa autorización administrativa, como los requisitos para la concesión de dichas autorizaciones» ${ }^{67}$.

El planeamiento no puede elaborarse al margen de otras normativas y también de las previsiones ya existentes. Un condicionante fundamental lo encontramos en el artículo 75.2 de la LTIB reconoce el carácter residencial de las viviendas de uso residencial si bien es cierto que entiende que la

${ }^{66}$ F.J. Décimo.

${ }^{67}$ Sentencia del Tribunal Supremo, n. ${ }^{\circ}$ 779/2021, de 2 de junio de 2021 en su F.J. Quinto. 
turística extraordinaria por lo tanto avala la aplicación de medidas correctoras por parte de los poderes públicos competentes En este sentido conviene recordar el tenor literal de dicho precepto: «tiene la consideración de zona apta para la comercialización de estancias turísticas en viviendas de uso residencial aquella en que, motivadamente, con las medidas correctoras que se puedan establecer y cumpliendo las previsiones establecidas legalmente o reglamentariamente en materia de vivienda, la administración competente para llevar a cabo la zonificación considere que esta utilización extraordinaria de las viviendas residenciales resulta compatible con el uso ordinario de vivienda que las caracteriza (...)».

Al igual que la normativa balear el vigente decreto andaluz sobre la materia opta por calificarlos de inmuebles situados en el suelo de uso residencial y en ambas legislaciones que el carácter turístico no depende tanto de la calificación del suelo, sino de los medios de comercialización utilizados por los explotadores y que tienen la naturaleza turística ${ }^{68}$.

Canarias, en un concepto de vivienda turístico particularmente amplio, entiende que son aquellas ubicadas en las en el ámbito de la comunidad autónoma que se encuentren edificadas conforme a las normas urbanísticas y cuenten con las preceptivas licencias; se excluyen expresamente del ámbito de aplicación del reglamento ordenador las edificaciones en suelos turísticos que se encuentran dentro de las zonas turísticas o de las urbanizaciones turísticas así como las viviendas ubicadas en urbanizaciones turísticas, urbanizaciones mixtas residenciales turísticas conforme a la ley de renovación y modernización turística canaria.

En muchas ocasiones se han esgrimido por nuestros gobernantes problemas y efectos negativos que no han podido precisarse ni cuantificarse convirtiéndose en meras proclamas políticas que, al final, han vulnerado derechos constitucionales. Es por ello que el propio Tribunal Constitucional ${ }^{69}$, ya

${ }^{68}$ La ley de turismo balear (LTIB) en su artículo 3.n) es un claro ejemplo de definición absolutamente amplia de canal de oferta turística que se define como: Todo sistema mediante el cual las personas físicas o jurídicas, directamente o a través de terceros, comercializan, publicitan o facilitan, mediante enlace o alojamiento de contenidos, la reserva de estancias turísticas en viviendas, bien sea por plazos de días o semanas con el límite establecido en el artículo 50 de esta ley, bien sea con prestación de algunos de los servicios previstos en el artículo 51 de la misma.

Entre otros, las agencias de viajes; las centrales de reserva; otras empresas de mediación u organización de servicios turísticos, incluidos los canales de intermediación a través de internet u otros sistemas de nuevas tecnologías de información y comunicación; las agencias inmobiliarias; así como la inserción de publicidad en medios de comunicación social, cualquiera que sea su tipo o soporte.

${ }^{69}$ Sentencia n. ${ }^{\circ}$ 157/2016, de 22 de septiembre, (BOE n. ${ }^{\circ} 263$, de 31 de octubre de 2016). Concretamente en su F.J. Noveno. 
como doctrina consolidada, exige a los poderes públicos que justifiquen sus actuaciones aportando datos precisos: «Como se afirma en la STC 193/2013, FJ 7, en estos casos el "Tribunal considera necesario que, dado que se trata de una excepción a la regla general de la libertad de acceso a una actividad de servicio como es la distribución comercial, el legislador autonómico aporte razones que justifiquen que los requisitos a que sujeta la localización de ciertos formatos de establecimiento comercial atienden conjuntamente a dichos objetivos de ordenación territorial y protección ambiental, y no a otros que están prohibidos por predominar en ellos connotaciones económicas". Y la STJUE de 24 de marzo de 2011, Comisión c. España (asunto C-400/08) ha establecido que "las razones que pueden ser invocadas por un Estado miembro para justificar una excepción al principio de la libertad de establecimiento deben ir acompañadas de un análisis de la oportunidad y de la proporcionalidad de la medida restrictiva adoptada por dicho Estado miembro, así como de los datos precisos que permitan corroborar su argumentación (véase la Sentencia de 22 de diciembre de 2008, Comisión/Austria, C-161/07, Rec. p. I-10671, apartado 36 y jurisprudencia citada).

El alto tribunal expone que para entender que concurren las razones imperiosas de interés general exigidas por la normativa básica estatal con el fin de establecer una restricción al principio de libertad de establecimiento no basta con que el legislador apele a tales razones, sino que es preciso que se aporten en el presente proceso los datos precisos en las que se justifica la adopción de la medida limitativa de acuerdo con tales razones, pues solo en tales casos podrá apreciarse, cuando surge una controversia sobre la constitucionalidad de la medida, que la limitación establecido tiene como finalidad la consecución de fines de interés general que la legitiman.

Ello implica exigir que las memorias justificativas de los instrumentos de planeamiento urbanístico deben encontrar una justificación suficiente sobre las determinaciones fundamentales que establecen, manifestando las razones por las que adoptan las decisiones esenciales contenidas en dicho plan que, además, es una exigencia prevista en el artículo 35 de la Ley 39/2015. La observancia o no de la motivación impuesta (con sucinta referencia de hechos y fundamentos de derecho) supondrá la nulidad del instrumento de planeamiento.

En este sentido destacamos por su ingente aportación de doctrina judicial la sentencia del Tribunal Superior de Justicia de Cataluña n. ${ }^{\circ} 323 / 2017$, de 29 de mayo, que declara la nulidad de la Modificación del Plan especial de establecimientos de concurrencia pública, hotelería y otras actividades en Ciutat Vella que acogiendo la doctrina del Tribunal Supremo nos recuerda ${ }^{70}$ :

70 F.J. Segundo. 
«En relación con el ejercicio por la Administración de la potestad discrecional en materia de planeamiento urbanístico, tiene declarado la sentencia de 15 de febrero de 2013, dictada en el Recurso de Casación 3128/2010:

En fin, resulta oportuno recordar nuestra jurisprudencia sobre la exigencia de justificación de las determinaciones que el plan alumbra, cuya expresión tiene su sede natural en la memoria del plan. Así, en Sentencia de 23 de marzo de 2012 (recurso de casación n. ${ }^{\circ}$ 2650/2008) hemos declarado que "Desde antiguo esta Sala viene declarando, por todas, las sentencias dictadas en apelación de 23 de junio de 1997 (recurso de apelación n. ${ }^{\circ}$ 13058/1991), 27 de diciembre de 1995 (recurso de apelación n. ${ }^{\circ}$ 5436/1991), y 25 de junio(sic) de 1996 (recurso de apelación n. ${ }^{\circ} 8533 / 1991$ ), entre otras muchas posteriores, que la memoria ha de contener justificación suficiente sobre las determinaciones fundamentales que establece, exteriorizando las razones por las que adopta las decisiones esenciales contenidas en el plan. Tal justificación es una exigencia en garantía de los intereses generales. En este sentido, la última sentencia citada declara que 'La Administración al planificar y al modificar no puede actuar con alejamiento de los intereses generales o con falta de motivación debidamente justificada, y siempre con observancia de los principios contenidos en el artículo 103 de la Constitución'". Igualmente en Sentencia de 30 de Noviembre de 2010 (recurso de casación n. ${ }^{\circ}$ 5617/2008) señalamos que "Esta Sala se ha pronunciado con reiteración acerca de la necesidad de motivación de los Planes de urbanismo. Así, en la STS de 5 de junio de 1995, Recurso de Apelación n. ${ }^{\circ}$ 8619/1990 —reiterando lo dicho, entre otras, en las SSTS de 25 de abril, 9 de julio y 20 de diciembre de $1.991,13$ de febrero, 18 de mayo y 15 de diciembre de 1.992 -, advertimos sobre el carácter trascendental de la motivación del Planeamiento, declarando que 'la amplía discrecionalidad del Planeamiento, conjunto normativo emanado de la Administración, con la repercusión que ello puede comportar en la regulación del derecho de propiedad —artículos 33.2 de la Constitución - justifica la necesidad esencial de la motivación de las determinaciones del planeamiento...'; y, en la más reciente STS de 26 de febrero de $2010, \mathrm{RC} \mathrm{n}^{\circ}{ }^{\circ} 282 / 2006$ indicamos que '... el control de la discrecionalidad administrativa en el orden urbanístico, ... impone que en el ejercicio de potestad discrecional, como presupuesto de legitimación, se han de explicar las razones que determinan la decisión. Y esta justificación ha de hacerse con criterios de racionalidad expresados en la memoria. Sólo así podremos diferenciar la discrecionalidad de la pura arbitrariedad"” (FJ 8).»

\section{CONCLUSIONES}

1. Es una exigencia y función de todos los poderes públicos garantizar el ejercicio de la libertad de empresa conforme establece el artículo 
38 , por lo tanto, la actuación administrativa debe defender el funcionamiento competitivo del mercado y no puede originar una limitación o restricción para dichos mercados. Únicamente puede encontrarse limitada en la potestad de intervención de la Administración Pública mediante normas que disciplinen razonablemente el mercado.

2. A la hora de valorar si una Comunidad Autónoma o un Ayuntamiento pueden limitar, restringir o prohibir el alquiler turístico en determinadas zonas (como ocurre en muchas ciudades y municipios de España) conviene recordar la Sentencia del Tribunal de Justicia de la Unión Europea de 30 de enero de 2018 que indica que la Directiva de servicios no se opone a que el acceso a una actividad de servicios o su ejercicio se supedite al respeto de un límite territorial de esta índole, siempre que se cumplan las condiciones de no discriminación, necesidad y proporcionalidad enunciadas en su artículo 15, apartado 3. Nos encontramos ante un expreso condicionamiento a los límites de carácter urbanístico o territorial (por ejemplo, mediante zonificaciones), que para ser validados deben cumplir con el test y los principios de buena regulación exigidos por el derecho europeo y también como fundamento de nuestro derecho administrativo.

3. No es suficiente invocar intereses generales para prohibir, limitar o restringir la prestación de un servicio. La falta de rigor en el cumplimiento e interpretación de las normas europeas y la definición y concreción de las razones imperiosas de interés general por parte de los legisladores autonómicos y municipales para introducir barreras de entrada sobre cualquier actividad económica sin más limitación y control que su propia voluntad implica vulnerar el derecho y la jurisprudencia europea. Como hemos indicado Directiva de servicios y las leyes de transposición que imponen solamente autorizar con carácter previo ante limitaciones por razones justificadas e imperiosas de interés general y nunca atendiendo a objetivos o motivos de planificación económica. Por lo tanto, todas aquellas medidas urbanísticas que meramente encubren razones puramente económicas y de planificación de la oferta de alojamiento deben ser proscritas y declaradas contrarias a nuestro ordenamiento jurídico

4. En diversas ocasiones y por parte de administraciones radicadas en distintos puntos de nuestro país queda patente que las externalidades negativas que han justificado determinadas medidas restrictivas para el mercado carecen de una documentación probatoria y se tratan de meros juicios de valor. Por lo tanto, es exigible esa tarea de justificación y búsqueda de la adecuación y proporcionalidad ante medidas 
que por dichas externalidades puedan restringir el establecimiento de operadores en el mercado o bien disuadirles de hacerlo.

5. Atendiendo a todo lo indicado a lo largo de este artículo podríamos plantearnos si existe una desviación de poder el actuación de los poderes públicos toda vez que a través de un procedimiento de carácter netamente urbanístico pretenden solventarse cuestiones que atañen a otros ámbitos como, por ejemplo, pueden ser los de convivencia y seguridad, políticas de acceso a la vivienda y su promoción pública o planificación de recursos medioambientales y que entendemos deben someterse a otros mecanismos de actuación.

\section{BIBLIOGRAFÍA}

AA.VV. (directores Alonso Sánchez R./Valero Torrijos, J.). Retos jurídicos de la economía colaborativa en el contexto digital (directores Alonso Sánchez y Valero Torrijos), Thomson Reuters, Aranzadi, Cizur Menor, 2017.

(Directores Muñoz, A./Rodríguez, S.). Aspectos legales de la economía colaborativa y bajo demanda en plataformas digitales, Bosch, Madrid 2018.

Boix Palop, A. «Economía colaborativa para el desarrollo local». En M. R. Alonso Ibáñez (dir.), La sostenibilidad socioeconómica de las ciudades: estudios jurídicos, Tirant lo Blanch, 2018.

Canedo Arrillaga, M. P. «Poderes públicos y competencia. En busca del efecto útil del Derecho de competencia», Cuadernos de derecho transnacional, Vol. 12, n. ${ }^{\circ} 2,2020$, págs. 226-253.

Desdentado Daroca, E. Discrecionalidad administrativa y planeamiento urbanistico, Aranzadi, Navarra, 1999.

Doménech Pascual, G. «La regulación autonómica y local de las viviendas de uso turístico», en Anuario de Derecho Municipal 2017, n. ${ }^{\circ} 11$.

Fernández Torres, J.R. «No todo vale a la hora de controlar las viviendas vacacionales», Revista Aranzadi de Urbanismo y Edificación n. ${ }^{\circ}$ 42/2018, Tribuna.

——Planificación urbanística y Directiva de servicios. El Tribunal de Justicia de la Unión Europea arroja luz», Revista Aranzadi de Urbanismo y Edificación n. ${ }^{\circ} 42 / 2018$, Tribuna, Parte Estudios.

Franch Fluxà, J. «La regulación de la vivienda de uso turístico en Baleares tras las últimas reformas legislativas» en AA.VV. (Directoras González Cabrera, I./Rodríguez M.P.) Las viviendas vacacionales: entre la economía colaborativa y la actividad mercantil, Dykinson, Madrid, 2019.

Fuentes-Lojo Rius, A. «Problemática del propietario múltiple en la adopción de acuerdos comunitarios», Diario La Ley, N. ${ }^{\circ}$ 9539, 18 de diciembre de 2019, Editorial Wolters Kluwer.

García Rubio, F. «El papel de la administración ante el turismo de plataformas» en AA.VV (director Franch Fluxà, J.) Economía de plataformas: retos y normativa, Atelier, Barcelona, 2020.

García de Enterría, E. y Fernández, T.R. Curso de Derecho Administrativo, Civitas, Thomson Reuters, Madrid, volumen II, 15. ${ }^{\text {a ed., }} 2017$. 
González Jiménez, P. M. (2017). «La oferta de viviendas de uso turístico a través de plataformas colaborativas: reflexiones desde el derecho de la competencia desleal», en Revista de Estudios Europeos, n. ${ }^{\circ}$ 70, julio-diciembre, 2017.

Goñi Rodríguez de Almeida, M. «El alquiler vacacional como actividad molesta en la comunidad de propietarios», Revista Crítica de Derecho Inmobiliario, n. ${ }^{\circ}$ 765, enero, 2018.

Gordillo Pérez, L. I./Rodríguez Ortiz, F. Constitución económica y gobernanza económica de la UE, Thomson-Aranzadi, Madrid, 2019.

Hinojo González, P. «La promoción de la competencia en el turismo colaborativo en la era digital» en AA.VV (director Franch Fluxà, J.) Economía de plataformas: retos y normativa, Atelier, Barcelona, 2020

Jiménez Soto I. «Ordenación de los servicios turísticos: competencias administrativas y unidad de mercado» en AA.VV. Vandelli, L./Font i Llovet T.) Ordenación jurídico-administrativa del Turismo, Atelier, Barcelona, 2018.

Maudes, A. «La aplicación de los principios de regulación económica eficiente al transporte colaborativo. El papel de la CNMC» en AA.VV. (editores Boix A./De la Encarnación A.M./Doménech G.) La regulación del transporte colaborativo, Thomson Reuters Aranzadi, Cizur Menor, 2017.

Muñoz Guijosa, M.A., El derecho de propiedad del suelo. De la Constitución a la ordenación urbana, Civitas, Madrid, 2009.

Rey Martínez, F. La propiedad privada en la Constitución española, Colección Estudios Constitucionales, Centro de Estudios Políticos y Constitucionales, Madrid, 1994.

Román Márquez, A. «Planificación urbanística del turismo: la regulación de las viviendas de uso turístico en Madrid y Barcelona». Revista De Estudios De La Administración Local y Autonómica, (10), 2018.

Rodríguez González, M.P. «Algunos aspectos cuestionables de la regulación actual de las viviendas vacacionales en Canarias, que evidencia la necesidad de su revisión» en AA.VV. (Directoras González Cabrera I./Rodríguez M.P.) Las viviendas vacacionales: entre la economía colaborativa y la actividad mercantil, Dykinson, Madrid, 2019.

Sarmiento Acosta. M.J. «Las normas especiales y ampliatorias de los usos en el suelo rústico por razón del turismo en las "Islas Verdes" de Canarias», Revista Aranzadi de Urbanismo y Edificación n. ${ }^{\circ}$ 44/2020, parte Estudios.

Serrano García, M. «La ordenación legal de los establecimientos de apartamentos turísticos en Andalucía». Revista Internacional de Turismo, Empresa y Territorio, 4 (2), 2020. 


\title{
RESTRICCIONES A LA LIBERTAD DE EMPRESA Y EL MERCADO EN LA NORMATIVA URBANÍSTICA APLICABLE A LAS VIVIENDAS VACACIONALES
}

\author{
Restrictions on the freedom of business and the market \\ in the urban regulations applicable to vacation housing
}

\author{
Juan Franch Fluxà \\ Profesor contratado doctor de Derecho Mercantil \\ Universitat de les Illes Balears
}

http://dx.doi.org/10.18543/ed-69(2)-2021pp43-76

\section{Copyright}

Estudios de Deusto es una revista de acceso abierto, lo que significa que es de libre acceso en su integridad. Se permite su lectura, la búsqueda, descarga, distribución y reutilización legal en cualquier tipo de soporte sólo para fines no comerciales, sin la previa autorización del editor o el autor, siempre que la obra original sea debidamente citada y cualquier cambio en el original esté claramente indicado

Estudios de Deusto is an Open Access journal which means that it is free for full access, reading, search, download, distribution, and lawful reuse in any medium only for non-commercial purposes, without prior permission from the Publisher or the author; provided the original work is properly cited and any changes to the original are clearly indicated. 